\title{
Title: Role of attitudes in Brazil's country brand image
}

\begin{abstract}
For past three decades, the academic community has sought to advance the analysis relating to the image of several countries around the world. In relation, several studies have since been published on contemporary relevance of the image of a given country, and its subsequent effects on product evaluations and purchase intentions, among other behavioural outcomes (Bloemer et at., 2009; Elliot, Papadopoulos \& Kim, 2011; Khan et al., 2012; Koschate-Fischer, Diamantopoulos \& Oldenkotte, 2012; Diamantopoulos, Schlegelmilch, Sinkovics, \& Bohlen (2003); Magnusson, Westjohn \& Zdravkovic, 2011; Maher \& Carter, 2001; Pappu \& Quester, 2010; Zeugner-Roth, Diamantopoulos \& Montesinos, 2008; Tseng \& Balabanis, 2011). Nonetheless, despite the importance of the theory of attitude in evaluating the image of a country, the majority of papers in the field has focused on the cognitive component of attitude only, having the other components, affective and conative, not thoroughly being examined (Brijs, 2006; Roth \& Diamantopoulos, 2009). As a result, with an aim to extend our current understanding into the role of attitudes on country brand image, this paper considers the conations more broadly such as, the predisposition for traveling, doing businesses, investing, working in the country, as well as, the willingness for either buying products made in the Brazil or shopping in the Brazil. Additionally, the purpose of this paper is to investigate Brazil's country brand image, based on the three-attitudinal categories "cognitive", "affective", and "conative".
\end{abstract}

The methodological approach taken in this study is a quantitative method via an online survey. The study population consisted of the 427 undergraduate students at foreign institutions partaking agreements with a Brazilian public university. Attitudes were analysed using exploratory factor analysis to correlate potential impact on Brazils' country brand image. The country's image refers to a construct derived from the concept of attitudes, being comprised of cognitive, affective, and conative components. Results of this study indicate that the conative dimension received the highest scores of the respondents implying strong behavioural intentions in relation to Brazil's country brand image. It is also noteworthy that the technical dimension presented a more negative assessment in comparison to all other dimensions of Brazil's image, indicating that such a cognitive element to be adequately developed to highlight better brand assurance.

Key words: Country branding, Brazil, country brand image, country-of-origin, attitudes 


\section{Background}

The academic community has sought to advance analysis of the national image of various countries around the world for past many years. One of the key aims of such studies was to understand how country brand images affect the decisions and attitudes of individuals. Several studies in this area have since been published on the contemporary relevance of the image of a given country, and its subsequent effects on product evaluations and purchase intentions, among other behavioural outcomes (e.g. Bloemer et al., 2009; Elliot, Papadopoulos \& Kim, 2011; Khan et al., 2012; Koschate-Fischer, Diamantopoulos \& Oldenkotte, 2012; Diamantopoulos et al. 2003; Magnusson, Westjohn \& Zdravkovic, 2011; Maher \& Carter, 2001; Pappu \& Quester, 2010; Zeugner-Roth, Diamantopoulos \& Montesinos, 2008; Tseng \& Balabanis, 2011). In view of this, the topic is relevant in order to further clarify country image building concepts embedded within country-of-origin effect construct. Nonetheless, despite the importance of the theory of attitude in evaluating the image of a country, the majority of papers in the field have focused on the cognitive component of attitude only, with the other components, affective and conative, not being thoroughly examined (Brijs, 2006; Roth \& Diamantopoulos, 2009). Roth and Diamantopoulos (2009) indicate that conations towards the country should not be limited to evaluations of or preferences for products. Other potential consequences, such as visits to the country and investments in the country should also be considered, or even "pre-existing perceptions" because of the multiple facets of a place (Skinner, 2008, p.923). As a result, with the aim of extending our current understanding of the role of attitudes in country brand image formation, this paper considers conations more broadly, and considers them to include predisposition for travelling, migration, doing business and investment, as well as willingness to either shop in the country or buy products made in the country.

Within this context, some studies have clearly demonstrated that the image associated with Brazil is still ambiguous and varied, including both positive and negative associations that might confuse foreign visitors (Benedetti, Cakmak \& Dinnie, 2011; Mariutti, Giraldi \& Crescitelli, 2013; O'Neil, 2007; Rezende-Parker, Morrison \& Ismail, 2003). Therefore, the purpose of this paper is to investigate Brazil's country brand image, based on all three attitudinal categories, cognitive, affective, and conative. Additionally, given the limited amount of research undertaken on the topic - especially with an external (non-Brazilian) sample (Lopes, Giraldi \& Aguiar, 2014), this paper adds to the growing literature on Brazil's image.

\section{Country Image Concept}

The term "country image", according to Bloemer, Brijs and Kasper (2009), relates to extrinsic attributes of the product, such as price, brand, and reputation of the store or guarantees. This concept may become an important strategic tool, expressing an emotional and intangible component that can affect decisions such as travel, investments, and purchase of products, among others. The literature on national stereotypes, as well as the perceptions that people have about nations, date from the 1930s (Roth \& Diamantopoulos, 2009). However, the concept of "country-of-origin" has only attracted notable attention from researchers in the field of marketing since the $1960 \mathrm{~s}$, since the intensification of trade and investment flows. In 1962, Dichter referred to the significance of information about the country of origin; since then, research on the so-called "country of origin effect" has become a major field of enquiry within both international marketing and consumer behaviour literature (Bloemer et al., 2009; Khan, Bamber \& Quazi, 2012), interestingly, interconnecting it to place branding and/or marketing (Olins, 2002; Skinner, 2008) from a country standpoint.

Olins (2012) traces the evolution of country branding from the country of origin construct due to the globalization phenomenon and competitiveness on the world stage, as does Skinner (2008), when calling place branding and place marketing "global forces [which] have grown the importance of services to the economy" (p.923). Nevertheless, according to Roth and Diamantopoulos (2009), the inconsistencies in defining the country image construct resulted in considerable confusion, with authors using different concepts to define it, such as perceptions, impressions, associations, stereotypes, schemas, and beliefs. However, these concepts are not broad enough to capture the whole domain of the construct of country image. In this sense, one approach that, we think, seeks to explain the country image formation is the attitude theory. 


\section{The Attitude Theory Role in Country Image}

Brijs (2006) points out that the literature on the country-of-origin effect covering the period between 1980 and 1990 is strongly based on attitudinal psychology, considering the images of countries as constructs similar to attitudes. Here, the term "attitude" denotes a learned predisposition to respond either favourably or unfavourably to a given object (Fishbein \& Ajzen, 1975). The three attitudinal categories are referred as "cognitive", "affective", and "conative". Roth and Diamantopoulos (2009), and Brijs (2006) believe that through the understanding of the cognitive, affective, and conative components that make up an attitude, one can evaluate the image of a country and its influence upon the behaviour of the target audience.

The cognitive component of the country brand image relates to knowledge, consisting of a complex network containing everything consumers know (or assume they know) about the country, its people and the products from that country-of-origin, together forming the so-called "beliefs" (Brijs, 2006; Bloemer et al., 2009). Bloemer et al. (2009) argued that the effects of affection differ from cognitions, because information about the country of origin would arouse purely emotional responses within consumers. For instance, Hede \& Watne's model (2013, p.218) suggest that for destination branding strategy, marketers should "create narratives that have the potential to humanise brands, meaning that consumers can ultimately develop emotional attachments with the humanised brand". Compared to the cognitive component, the affective component tends to have a more immediate effect on engagement and subsequent purchase intentions (Orbaiz \& Papadopulos, 2003; Heslop et al., 2004; Brijs, 2006).

In relation, a study by Khan et al. (2012) examined the link between the country of origin of products and purchasing decisions, using means-end chain (MEC) analysis. Within the 'means' category were attributes of the product and the association of the self with the product; while the elements in the 'consequences' category were rooted in the cultural psyche of consumers, becoming attached to consumers' emotions when compared to the functionality of product attributes. The researchers "revealed a close link between consumers' liking for foreign products connected with how they valued those products both psychologically and physiologically" (Khan et al. 2012, p.1190). Later, they showed that this link influences "the purchaser's attitudes to different products from various countries, which in turn influence the purchaser's willingness to buy a particular product from a particular country" (Khan et al., 2012, p.1210). However, there is still a dearth of research investigating affective and conative attitudes in relation to country brand image (Brijs, 2006; Roth and Diamantopolous, 2009).

Moreover, in line with the conclusions drawn by Skinner (2008, p.923) that

as places compete in a global marketplace, economic regeneration is deemed of importance to those interested in regional studies, urban studies, tourism, for those wishing to market products using a positive country of origin effect, and, latterly, is now linked to the idea that a place can be managed and marketed for wider positive effects,

The purpose of this paper is to understand and further investigate into the role of cognitive, conative and affective attitudes on country brand image in the Brazilian context.

\section{Methodology}

The methodological approach taken in this study is quantitative, with data gathered via an online survey. The study population consisted of undergraduate students at foreign institutions partaking in agreements with a Brazilian public university using non-probabilistic approach. The survey questionnaire was hosted online, and respondents directed to it through a link placed in an e-mail invitation.

For the operationalization of the variable "cognitive dimension of country image," we used the scale proposed by Pappu, Quester and Cooksey (2007), and Pappu and Quester (2010), who adapted the scale of Martin and Eroglu (1993), to obtain the macro image of the country. 
Regarding the operationalization of the affective component, Roth and Diamantopoulos (2009) point out that relatively few studies have employed a robust affective-related measurement towards the country, such as Brijs (2006), and D'Astous and Boujbel (2007). To assess the affective component of attitude towards Brazil, this paper uses the scale developed by Brijs (2006), which was itself adapted from the PANAS scale developed by Watson, Clark and Tellegen (1988) with the scale items transformed into a seven-point semantic differential construct. Ten statements were designed to assess the affective dimension of the image of Brazil.

For the operationalization of the conative dimension of the image of Brazil, the paper again builds on the work of Brijs (2006), which developed an itemized scale related to conations upon the country (covering shopping, working, buying products made in the country, doing business and investing in the country). In this research, an additional statement was added to those used by Brijs (2006), to include another behaviour intention in relation to the country: the willingness to travel. Thus, another major target audience for communication of Brazil's brand and image should be covered in this research tourists.

Figure 1 shows the research variables and their operationalization:

Figure 1

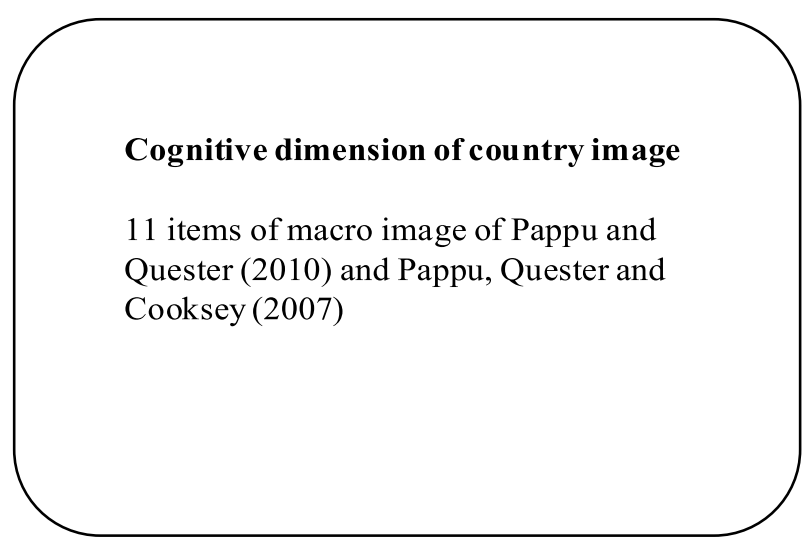

Affective dimension of country image

10 items of positive feelings of Brijs (2006)

Conative dimension of country image

5 items of behavioural intentions of Brijs (2006) plus one added intention (willingness to travel)

\section{Findings and Discussion}

A total of 427 questionnaires were conducted and analysed, with responses collected via an online survey. As far as the sample profile is concerned, the average respondent age was 22.9 years old, with a standard deviation of 4.3 years. Amongst participants, female (52\%) had a slight majority versus $48 \%$ of male respondents. The nationalities most heavily represented in the sample were France $(32.8 \%)$, Italy (32.3\%) and Belgium (13.6\%) with other diverse nationalities representing remaining respondents altogether $(21.3 \%)$. The factor analysis used the criterion of eigenvalues greater than 1 for extracting factors. Five factors with eigenvalues greater than 1 were obtained, and together explained $64.89 \%$ of the total variance of the elements $(\mathrm{KMO}=0.923)$. In accordance with Hair et al. (1995), the rotation of the factors obtained for the questions on the dimensions of Brazil's image was carried out by employing the Varimax method. Table 1 shows the factor loads obtained. Values lower than 0.2 were omitted for better readability. 
Table 1 - Rotated Component Matrix - Brazil's Image Dimensions

\begin{tabular}{|c|c|c|c|c|c|}
\hline \multirow{2}{*}{ Statement } & \multicolumn{5}{|c|}{ Factors } \\
\hline & 1 & 2 & 3 & 4 & 5 \\
\hline $\begin{array}{l}\text { To which extent do Brazil and Brazilian } \\
\text { people make you feel active }\end{array}$ & 0.759 & & & & \\
\hline $\begin{array}{l}\text { To which extent do Brazil and Brazilian } \\
\text { people make you feel strong }\end{array}$ & 0.756 & & & & 0.286 \\
\hline $\begin{array}{l}\text { To which extent do Brazil and Brazilian } \\
\text { people make you feel inspired }\end{array}$ & 0.717 & 0.301 & 0.234 & & \\
\hline $\begin{array}{l}\text { To which extent do Brazil and Brazilian } \\
\text { people make you feel proud }\end{array}$ & 0.716 & & & & 0.362 \\
\hline $\begin{array}{l}\text { To which extent do Brazil and Brazilian } \\
\text { people make you feel determined }\end{array}$ & 0.685 & 0.287 & 0.204 & & 0.208 \\
\hline $\begin{array}{l}\text { To which extent do Brazil and Brazilian } \\
\text { people make you feel excited }\end{array}$ & 0.683 & 0.484 & & & \\
\hline $\begin{array}{l}\text { To which extent do Brazil and Brazilian } \\
\text { people make you feel enthusiastic }\end{array}$ & 0.672 & 0.447 & & & \\
\hline $\begin{array}{l}\text { To which extent do Brazil and Brazilian } \\
\text { people make you feel interested }\end{array}$ & 0.625 & 0.513 & & & \\
\hline $\begin{array}{l}\text { To which extent do Brazil and Brazilian } \\
\text { people make you feel attentive }\end{array}$ & 0.586 & & & & 0.550 \\
\hline I would like to do business with Brazil & & 0.820 & & 0.239 & 0.223 \\
\hline I would like to invest in Brazil & & 0.754 & & 0.239 & 0.255 \\
\hline I would like to work in Brazil & 0.262 & 0.742 & 0.251 & & \\
\hline $\begin{array}{l}\text { I would like to buy products that are } \\
\text { made in Brazil }\end{array}$ & 0.213 & 0.703 & 0.275 & & \\
\hline I would like to shop in Brazil & 0.281 & 0.702 & & & \\
\hline I would like to travel to Brazil & 0.331 & 0.685 & & & \\
\hline $\begin{array}{l}\text { Brazil is a producer of high- quality } \\
\text { products }\end{array}$ & & 0.262 & 0.774 & & \\
\hline Brazil has high labor costs & 0.268 & & 0.713 & & \\
\hline $\begin{array}{l}\text { Brazil has a high level of technological } \\
\text { research }\end{array}$ & & 0.259 & 0.711 & & \\
\hline Brazil has a high standard of living & 0.262 & & 0.672 & & \\
\hline $\begin{array}{l}\text { Brazil has a high level of } \\
\text { industrialization }\end{array}$ & & 0.256 & 0.625 & 0.314 & 0.206 \\
\hline Brazil has a welfare system & 0.226 & & 0.589 & 0.327 & \\
\hline $\begin{array}{l}\text { Brazil has a highly developed } \\
\text { economy }\end{array}$ & & 0.347 & 0.551 & 0.400 & 0.254 \\
\hline Brazil is democratic & & 0.238 & & 0.816 & \\
\hline
\end{tabular}




\begin{tabular}{|l|l|l|l|l|l|}
\hline Brazil has a free-market system & & & & 0.767 & \\
\hline $\begin{array}{l}\text { Brazil has a Civilian non- military } \\
\text { government }\end{array}$ & & & & 0.765 & \\
\hline Brazilian people are literate & & 0.225 & 0.450 & 0.476 & 0.214 \\
\hline $\begin{array}{l}\text { To which extent do Brazil and Brazilian } \\
\text { people make you feel alert }\end{array}$ & 0.359 & & & & 0.695 \\
\hline
\end{tabular}

Factor 1, which embodies statements on feelings aroused by Brazil, explains $35.6 \%$ of the total variance of the elements and has internal consistency (alpha coefficient) equal to 0.901, after the exclusion of one item ("To which extent do Brazil and Brazilian people make you feel attentive"), that had high loads in two different factors. It is observed that Factor 1 represents elements related to feelings towards Brazil, being consistent with the affective dimension by country image, as proposed by Brijs (2006), in alignment with the theory of attitude articulated by Fishbein and Ajzen (1975). This paper complements literature in the field by identifying and operationalizing a dimension of country image related to affection, a component considered undervalued by studies (Brijs, 2006; Roth \& Diamantopoulos, 2009). Factor 1 is thus named as the "affective dimension" of country image.

Factor 2 explains $11.8 \%$ of the total variance and its internal consistency is equal to 0.899 . In comparison with the work of Brijs (2006), the result has greater reliability, since the conative factor in exploratory factor analysis conducted by the authors obtained an alpha value equal to 0.74 . The composition of Factor 2 relates to the theory of attitude, referring to actions and verbal expressions of behaviour (Fishbein \& Ajzen, 1975), thereby capturing consumer behavioural intentions towards the country of origin. Thus, Factor 2 is named as "conative dimension" of country image.

Factor 3 explains $7.7 \%$ of the total variability of the analysed elements and the value of Cronbach's alpha is equal to 0.845 . Factor 3 of country image is aligned with the theory, standing consistent with the definition of Martin and Eroglu (1993), that the image of a country is the sum of all informational, inferential, and descriptive beliefs which an individual has about a particular country. The studies of Pappu et al. (2007) and Pappu and Quester (2010), which served as the basis for the construction of the survey sentences, demonstrated the existence of the "macro" dimension referring to country image.

Nevertheless, the dimension identified by the authors had eleven statements, instead of seven, as in this case. The statements that did not group by Factor 3 are arranged in Factor 4, to be discussed below. Therefore, in this research, the cognitive dimension of the country image comprises more than one factor. By considering aspects related to the level of technological advancement of the country, Factor 3 is named as "technical dimension" of country image.

Factor 4 explains $5.63 \%$ of the total variability of the analysed elements. As previously mentioned, it is composed of statements related to the cognitive dimension of country image (as is Factor 3). The value of Cronbach's alpha is equal to 0.769 , after the exclusion of one item that had high loads in more than one factor ("Brazilian people are literate"). Factor 4 aligns with the definition of Martin and Eroglu (1993). The factors cited are part of the "macro" dimension of the image of the country identified by Pappu et al. (2007) and Pappu and Quester (2010). In comparison to the original dimensions of Martin and Eroglu (1993), Factor 4 has several items of the political dimension. Since, Factor 4 contemplates elements related to political decisions of the country, it is named as "political dimension" of country image.

Finally, Factor 5 consists of only one statement, concerning the feelings aroused by Brazil as a conceptual entity in general ("To which extent do Brazil and Brazilian people make you feel alert"), explaining only $4.15 \%$ of the total variance of the elements. Since a reliable dimension representing the affective aspects of Brazil (Factor 1) already exists, Factor 5 will not be considered in further analysis. 
In general, there is a similarity between the dimensions of country image derived from the sample used and those observed in the theory of country image (Martin \& Eroglu, 1993, Pappu et al., 2007, Pappu \& Quester, 2010; Roth \& Diamantopoulos, 2009). Such instance clearly demonstrates theoretical support for the empirical results of this study, suggesting face validity.

In order to sort the dimensions regarding the image of Brazil and to compare their scores, a composite measure was created from the average of the answers to the questions that comprise the factors cited. For Hair et al. (1995), the use of composite measures is more appropriate than the scores of individual factors, when the intention is to replicate the studies. However, it should be noted that questions relating to the cognitive (technical and political) and conative dimensions of the scale on the image of Brazil have eleven points, whereas issues relating to the affective dimension display seven points. Thereby, to compare the average scores of the dimensions, it was necessary to perform a linear transformation of the scale of the affective dimension of seven to eleven-point. Thus, all scales of Brazil's image have gained the same score, with the same valence (the closer to eleven the score is, the more positive assessments of the dimensions concerning the image of Brazil shall be).

In examining Table 2, which displays the descending order of the dimensions concerning the image of Brazil, it appears that the conative dimension received the highest scores (mean of 7.87), while the lowest score was for the technical dimension (mean of 5.49).

\begin{tabular}{|l|c|r|r|r|c|}
\hline \multicolumn{7}{|c|}{ Table 2 - Descriptive Statistics dimensions of Brazil's image } \\
\hline & N & Minimum & Maximum & Mean & Std. Deviation \\
\hline Conative & 427 & 1.00 & 11.00 & 7.87 & 2.12 \\
\hline Political & 427 & 1.00 & 11.00 & 7.37 & 1.84 \\
\hline Affective & 427 & 1.00 & 11.00 & 7.32 & 1.96 \\
\hline Technical & 427 & 1.00 & 9.57 & 5.49 & 1.36 \\
\hline Valid N (listwise) & 427 & & & & \\
\hline
\end{tabular}

Therefore, the technical dimension provides a more negative assessment in comparison to all other dimensions of the image of Brazil. Additionally, we note that the other cognitive aspect of the country (political) also has less favourable evaluations than those of the conative dimension, displaying a similar score in comparison to the affective dimension (mean of 7.37). Thus, it can be seen that cognitive and affective aspects towards Brazil have had more negative evaluations than the conative aspect.

\section{Conclusion}

The country's image refers to a construct derived from the concept of attitudes, being comprised of cognitive, affective, and conative components. Results of this study indicate that the conative dimension received the highest scores of the respondents implying strong behavioural intentions in relation to Brazil's country brand image. It is also noteworthy that the technical dimension presented a more negative assessment in comparison to all other dimensions of Brazil's image, indicating that such a cognitive element to be adequately developed, improvement in infrastructure is required, supported by adequate advertisement to provide better brand assurance. These results suggest that the theoryunderpinning themes in this paper, for instance, country of origin, consumer behaviour and place branding are interrelated when discussing country image constructs, along with the three attitudinal components - cognitive, affective, and conative.

\section{Implications}

As for the theoretical implications, the outcomes of this study make a significant contribution to the current research into country image components, especially by analysing the conations in a broader 
perspective. Many previous papers either made no distinction between the various aspects of the country image (cognitive, affective, and conative) or omitted to operationalize the affective and conative aspect (Roth \& Diamantopoulos, 2009). This paper addressed different dimensions regarding the image of Brazil separately, based on the theoretical framework of attitude. Consequently, the paper also provides additional evidence with respect to the cognitive component of attitude, which plays a relevant role in country image studies, besides the affective and conative components. Considerably more work is still to be done to determine the challenges facing Brazil in relation to its image abroad. Not only regarding these dimensions investigated but also research focused on marketing, communications and media channels, contents, and messages.

Another, more specific, contribution is the provision of new insights regarding the image of Brazil in a foreign market. The country image has shown to be ambiguous in previous studies (Benedetti, Cakmak \& Dinnie, 2011; Mariutti, Giraldi \& Crescitelli, 2013; O'Neil, 2007; Rezende-Parker, Morrison \& Ismail, 2003), and an explanation for this fact can be partially seen from this paper's results: although some cognitive dimensions of Brazil do not receive high ratings, the overall conations towards the country are strong, which can be an indication that other elements of the country image (more subjective and emotional ones) can influence such conations.

Amongst the managerial implications, the assessment of Brazil's image performed in this study can provide valuable information to help design an attractive brand image for various stakeholders, including policy makers who are also responsible for planning marketing programmes, and for companies promoting their products overseas. Although the study has successfully demonstrated that the cognitive dimension by means of technical and political elements does currently exist in the global context of a country image, it has certain limitations in terms of the methodological aspects: it is worth noting the target population defined for this study, which does not cover other important segments of purchasers for Brazilian products such as housewives, self-employed professionals, and high-income consumers residing in countries other than those of the respondents participating in the research. Moreover, the fact that a probabilistic sample was not used made it impossible to generalize the results for the population investigated. The use of a student sample is also a limitation here.

Further research concerning the role of the cognitive component in country image investigation would be worthwhile; it would be recommended to apply this investigation structure with participants from other countries and/or from another selection of the population. It is suggested that the associations of the cognitive component are also investigated in future studies. 


\section{References}

Benedetti, G., Cakmak, E. and Dinnie, K. (2011) The competitive identity of Brazil as a Dutch holiday destination. Place Branding and Public Diplomacy,7(2), 107-115.

Bloemer, J., Brijs, K., \& Kasper, H. (2009). The CoO-ELM model: A theoretical framework for the cognitive processes underlying country of origin-effects. European Journal of Marketing, 43(1-2), 6289.

Brijs, K. (2006). Unravelling country-of-origin: Semiotics as a theoretical basis for a meaningcentred approach towards country-of-origin effects. (Unpublished doctoral dissertation). Radboud Universiteit Nijmegen, Nijmegen, Netherlands.

D'Astous, A., \& Boujbel, L. (2007). Positioning countries on personality dimensions: Scale development and implications for country marketing. Journal of Business Research, 60(3), 231-239.

Diamantopoulos, A., Schlegelmilch, B. B., Sinkovics, R. R., \& Bohlen, G. M. (2003). Can sociodemographics still play a role in profiling green consumers? A review of the evidence and an empirical investigation. Journal of Business Research, 56(6), 465-480.

Dinnie, Keith. (2009) Nation Branding: Concepts, Issues, Practice. Oxford: Elsevier.

Elliot, S., Papadopoulos, N., \& Kim, S. S. (2011). An integrative model of place image: Exploring relationships between destination, product, and country images. Journal of Travel Research, 50(5), 520-534.

Fishbein, M., \& Ajzen, I. (1975). Belief, attitude, intention and behavior: An introduction to theory and research. Reading, MA: Addison-Wesley.

Giraldi, J. M. E., Giraldi, I. M. E., \& Scaduto, A. A. (2011). Brazil's image as a social representation process. African Journal of Business Management, 5(22), 8821-8831.

Guina, F. T. C., \& Giraldi, J. M. E. (2012). Differences on the image of Brazil in external markets according to consumers age, gender, knowledge about the country and country of residence.

International Journal of Business Science and Applied Management, 7(2), 13-28.

Hair, J. F., Anderson, R. E., Tatham, R. L., \& Black, W. C. (1995). Multivariate data analysis. Upper Saddle River, NJ: Prentice Hall.

Han, C. M. (1989). Country image: Halo or summary construct? Journal of Marketing Research, 26(2), 222-229.

Heslop, L. A., Papadopoulos, N., Dowdles, M., Wall, M., \& Compeau, D. (2004). Who controls the purse strings: A study of consumers' and retail buyers' reactions in an America's FTA environment. Journal of Business Research, 57(10), 1177-1188.

Hede, A. \& Watne, T. (2013) Leveraging the human side of the brand using a sense of place: Case studies of craft breweries. Journal of Marketing Management, 29 (1-2), 207-224. 
Khan, H; Bamber, D. \& Quazi, A. (2012) Relevant or redundant: Elite consumers' perception of foreign-made products in an emerging market, Journal of Marketing Management, 28 (9-10), 11901216.

Koschate-Fischer, N., Diamantopoulos, A., \& Oldenkotte, K. (2012). Are consumers really willing to pay more for a favorable country image? A study of country-of-origin effects on willingness to pay. Journal of International Marketing, 20(1), 19-41.

Lopes, I. B., Giraldi, J. M. E., Aguiar, L. K. (2014) An Analysis of Country Image of Brazil and Its Fresh Fruits: A Two Scales Comparison. Journal of Food Products Marketing, 20(3), 262-282.

Magnusson, P., Westjohn, S. A., \& Zdravkovic, S. (2011). What? I thought Samsung was Japanese: Accurate or not, perceived country of origin matters. International Marketing Review, 28(5), 454-472.

Maher, A. A., \& Carter, L. L. (2011).The affective and cognitive components of country image: Perceptions of American products in Kuwait. International Marketing Review, 28(6), 559-580.

Mariutti, F. G., Giraldi, J. M. E., \& Crescitelli, E. (2013). The image of Brazil as a tourism destination: An exploratory study of the American market. International Journal of Business Administration, 4(1), $13-22$.

Martin, I. M., \& Eroglu, S. (1993). Measuring a multi-dimensional construct: Country image. Journal of Business Research, 28(3), 191-210.

Nebenzhal, I. D.; Jaffe, E. D. (1997). Measuring the joint effect of brand and country image in consumer evaluation of global products. Journal of Marketing Practice, 3 (3), 190-205.

Olins, W. (2002) Branding the nation: the historical context. Journal of Brand Management, London, 9, 4 (5), 241-248.

O’Neil, I. (2007). British travelers' image perspectives of Brazil as a tourism destination. Observatório de Inovação do Turismo, 1(4), 2-24.

Orbaiz, L.V., \& Papadopoulos, N. (2003). Toward a model of consumer receptivity of foreign and domestic products. Journal of International Consumer Marketing, 15(3), 101-126.

Pant, D. R. (2005). A place brand strategy for the Republic of Armenia: 'Quality of context' and 'Sustainability' as competitive advantage. Place Branding, 1(3), 273-282.

Pappu, R., \& Quester, P. G. (2010). Country equity: Conceptualization and empirical evidence. International Business Review, 19(3), 276-291.

Pappu, R., Quester, P. G., \& Cooksey, R. W. (2007). Country image and consumer-based brand equity: Relationships and implications for international marketing. Journal of International Business Studies, 38(5), 726-745.

Rezende-Parker, A. M., Morrison, A. M., Ismail, J. (2003). Dazed and confused? An exploratory study of the image of Brazil as a travel destination. Journal of Vacation Marketing, 9 (3), 243-259.

Roth, M. S., \& Diamantopoulos, A. (2009). Advancing the country image construct. Journal of Business Research, 62(7), 726-740.

Singh, R. K., Murty, H. R., Gupta, S. K., \& Dikshit, A. K. (2012). An overview of Sustainability assessment methodologies. Ecological Indicators, 15(1), 281-299. 
Skinner, H. (2008) The emergence and development of place marketing's confused identity. Journal of Marketing Management, 24 (9-10), 915-928.

Tseng, T.-H., \& Balabanis, G. (2011). Explaining the product-specificity of country-of-origin effects. International Marketing Review, 28(6), 581-600.

Watson, D., Clark, L. A., \& Tellegen, A. (1988). Development and validation of brief measures of positive and negative affect: the PANAS scales. Journal of Personality and Social Psychology, 54(6), 1063-1070.

Zeugner-Roth, K. P., Diamantopoulos, A., \& Montesinos, M. A. (2008). Home country image, country brand equity and consumers' product preferences: An empirical study. Management International Review, 48(5), 577-602. 